\title{
Bioactivity of Cyanobacterial Biomass Related to Amino Acids Induces Growth and Metabolic Changes on Seedlings and Yield Gains of Organic Red Beet
}

\author{
Átila Francisco Mógor*, Juliana de Oliveira Amatussi, Gilda Mógor, Gabriel Bocchetti de Lara \\ Universidade Federal do Paraná, Rua dos Funcionários, Curitiba, Brazil \\ Email: *afmogor@gmail.com
}

How to cite this paper: Mógor, A.F., de Oliveira Amatussi, J., Mógor, G. and de Lara, G.B. (2018) Bioactivity of Cyanobacterial Biomass Related to Amino Acids Induces Growth and Metabolic Changes on Seedlings and Yield Gains of Organic Red Beet. American Journal of Plant Sciences, $\mathbf{9}$, 966-978.

https://doi.org/10.4236/ajps.2018.95074

Received: February 27, 2018

Accepted: April 16, 2018

Published: April 19, 2018

Copyright $\odot 2018$ by authors and Scientific Research Publishing Inc. This work is licensed under the Creative Commons Attribution International License (CC BY 4.0).

http://creativecommons.org/licenses/by/4.0/

\begin{abstract}
In order to increase the understanding about Arthrospira platensis biomass use to plant growth promotion, the aim of this study was to determine total free amino acid content on lyophilized biomass and the biomass bioactivity on bioassay, as well as, the effects of foliar applications of aqueous suspension of biomass on seedlings growth ascertaining biochemical variables related to the potential bioactivity, and also at field on organically grown red beet yield. The results identified the bioactivity and expressed well the capacity of plant growth promotion related to stimulus on chlorophyll synthesis and on amino acid and protein increments on seedlings leaves. The yield had significant improvement related to hypocotyl growth. The results could be justified by the content of free amino acids on biomass, being them the highest amount of potential bioactive compounds of cyanobacteria. The Arthrospira platensis lyophilized biomass could be considered an efficient biofertilizer-biostimulant source, promoting yield gains by a sustainable way.
\end{abstract}

\section{Keywords}

Biostimulant, Biofertilizer, Microalgae, Plant Growth Promotion

\section{Introduction}

Organic agriculture offers methods for minimizing harmful residues and contributes on food production systems for sustainability [1]. In this way, as a tool for organic production, the study of cultivated microalgae as a source for plant growth promotion can lead to a sustainable way to improve yield, connected to 
the growing demand for food allied to the consumer's awareness for choosing healthy food.

As a natural friendly biomass, which offers interesting potential, microalgae is unicellular and multicellular photosynthetic microorganisms that can be found in freshwater and marine systems [2]. Common microalgae application is related to aquiculture, for direct and indirect feeding of fish, crustaceans and mollusk. For human consumption, microalgae biomass can be commercialized as a food supplement in different sources; furthermore, nutritional biomass and pharmaceutical compounds can be extracted from them. Other applications involve the treatment of wastewater from industrial processes, biological detoxification, heavy metal removal, soil bioremediation and biofuel production [3].

Among the numerous applications of microalgae, their use in agriculture was reported attributing a biofertilizer effect to the extract of the cyanobacteria Nostoc entophytum and Oscillatoria angustissima, promoting growth and increasing yield in pea plants [4], also was observed increased growth and concentration of macronutrients in wheat plants after the application of aqueous extract from the freshwater microalgae Scenedesmus sp. [5], and an effect in plant growth promotion in wheat plants submitted to Anabaena sp. microalgae extract applications [6]. Therefore, microalgae represents a potential sustainable alternative for the enhancement of agricultural crops [7].

Between these, Arthrospira platensis (also known as Spirulina platensis) is a filamentous cyanobacterium [8]. It is a Gram-negative specie that can grow in tropical and subtropical waters with $\mathrm{pH}$ between 8 and 11 and high carbonate and bicarbonate concentrations [2]. A. platensis has a protein-rich biomass with values of approximately of $60 \%$ on dry weight [8].

The presence of phytohormones as auxins, gibberellins, cytokinins and abscisic acid inside this cyanobacterial cells or exogenously released by them, with potential plant growth promotion effect are being documented [9]. The $A$. platensis composition also presents high levels of L-amino acids [10] around 58\% of their total protein content [11], which also may help in plant growth [12]. It was reported that one of the bioactive molecules on $A$. platensis is their polyamine content, mainly spermidine, which biosynthesis depends on L-amino acids and could stimulate cell multiplication and plant growth [13].

Regarding to Brazilian regulations, microalgae with plant growth promotion capacity could be a part of a class of products defined as biofertilizers, natural sources that can act directly or indirectly on all or parts of the cultivated plants, enhancing their yield [14], with use allowed for organic agriculture [15], so being a natural input for organic vegetables production.

Among fresh vegetables consumption, red beet (Beta vulgaris) is widely used and ranked between the ten most produced vegetable crops in Brazil [16]. From the Chenopodiaceae Family, red beet is a sweet flavored hypocotyl, red colored by betalain pigments [17]. This vegetable is originated from the temperate cli- 
mate of European and North-African regions, presenting good adaptation for a range of weathers and its yield could vary from 25 to $40 \mathrm{t} \cdot \mathrm{ha}^{-1}$ [18]. It is usually grown through direct sowing, but seedling use is also possible and it can help increasing yield and its quality [19].

In order to increase the understanding about $A$. platensis biomass use as biofertilizer, the aim of this study was to determine total free amino acid content on lyophilized biomass and evaluate their bioactivity. As well as the effects of foliar applications of aqueous suspension of biomass on red beet seedlings growth, determining biochemical variables related to the potential bioactivity, and at field on organically grown red beet yield.

\section{Material and Methods}

The cyanobacterium strain was provided by the "Elizabeth Aidar" Microalgae Collection from the Fluminense Federal University, Niteroi, Rio de Janeiro-Brazil. The autotrophic axenic cultivation of $A$. platensis was performed in a semi-continuous cultivation system in a photobioreactor [20], using culture medium [21] at the Plant Science and Crop Protection Department of the Federal University of Paraná, Paraná State, South of Brazil. After 60 days of cultivation, the biomass was separated from the culture medium by centrifugation, reaching $2.15 \mathrm{~g} \cdot \mathrm{L}^{-1}$ of dry weight $(d w)$ and it was lyophilized. The total free amino acid content on lyophilized biomass was determined using $50 \mathrm{mg}$ of the sample and $10 \mathrm{~mL}$ of $80 \%$ ethanol to prepare an extract [22]. After this, $1.0 \mathrm{ml}$ of extract was transferred to the assay tube. Then, $3.8 \mathrm{~mL}$ of Ninhydrin reagent was added and tubes were heated in a boiling water bath for $12 \mathrm{~min}$. The samples were analyzed at $570 \mathrm{~nm}$ using UV, visible spectrophotometer, compared with the standard leucine solution [23] and expressed on $\mathrm{mg} \cdot \mathrm{g}^{-1} d w$.

In order to identify a possible bioactivity for plant growth promotion of $A$. platensis lyophilized biomass $(A p b)$, mung bean (Vigna radiata) rooting bioassay [24] was performed, testing $A p b$ concentrations of $0.0,1.0,2.0$ and $3.0 \mathrm{~g} \cdot \mathrm{L}^{-1}$ on distilled water, with six replications. The mung bean roots lengths $(n=10)$ were determined by WinRhizo ${ }^{\circledR}$ software, coupled with a LA1600 3D Scanner (Regent Instruments Inc., Canada), it being expressed on $\mathrm{cm}$.

The seedlings growth experiment was conducted under a protected environment (polyethylene film covered nursery). The sowing of Early Wonder 2000 $\left(\right.$ Top Seed ${ }^{\circledR}$ ) red beet variety was done in 288 cells trays of expanded polystyrene, filled with Pro Vaso ${ }^{\circledR}$ and Plantmax ${ }^{\circledR}$ substrates, in the ratio of 1:1.5, respectively.

At completely randomized design with 5 replicates, foliar applications was done at 14 and 21 days after sowing (das) using aqueous suspensions of $A p b$ at concentrations of $0.75,1.5,2.25$ and $3 \mathrm{~g} \cdot \mathrm{L}^{-1}$, and the control (distilled water). The foliar sprays were done using a $\mathrm{CO}_{2}$-pressurized sprayer with constant pressure ( $45 \mathrm{psi})$ at $50 \mathrm{~mL}$ per replication.

The seedlings were collected at 32 das presenting five leaves. Fifteen seedlings of each replication were randomly selected and the following variables were 
analyzed: height of seedlings aerial part (hap); leaf area (la); fresh weight ( $f w$ ) and dry weight $(d w)$ of leaves and dry weight of roots $(d w r)$ and roots length $(r I)$. To obtain hap it was used a graduated ruler; measurements were done from the insertion of the leaves on hypocotyl until to their extremity. To obtain la and $r l$ the samples were also analyzed by WinRhizo ${ }^{\circledR}$ software coupled with a LA1600 3D Scanner (Regent Instruments Inc., Canada).

To obtain the dry weight, both aerial parts and roots were placed in paper bags and oven-dried at $65^{\circ} \mathrm{C} \pm 5^{\circ} \mathrm{C}$ with forced air circulation. The fresh and dry weight were determined with an analytical balance.

Relative chlorophyll content in seedling leaves was determined using the portable chlorophyll meter N-Tester ${ }^{\circledR}$ (Yara 2000) [25] at 30 das. Non-destructive readings were done.

For biochemical analysis, leaf samples were collected between 9:00 a.m. and 10:00 a.m., and then they were macerated with liquid nitrogen until a fine powder was obtained. Values were expressed as $\mu \mathrm{g}$ of metabolite per $\mathrm{g}$ of fresh mass. Chlorophylls were extracted with $80 \%$ acetone in distilled water and the addition of $0.1 \% \mathrm{CaCO}_{3}(\mathrm{p} / \mathrm{v})$ [26] [27] and readings were performed on UV-visible spectrophotometer at 663, 647 and $470 \mathrm{~nm}$, and expressed on $\mathrm{mg} \cdot \mathrm{g}^{-1}$ [28].

Total sugar [29] and reducing sugar [30] were determined. A standard curve was obtained with glucose at $1 \mathrm{mg} \cdot \mathrm{mL}^{-1}(5.5 \mathrm{mM})$, with values between 50 and $800 \mu \mathrm{g} \cdot \mathrm{mL}^{-1}$. Non-reducing sugar was calculated by subtracting reducing sugar from the total sugar.

Total free amino acids were extracted [31]. Colorimetric reaction was performed [32] with $1 \mathrm{~mL}$ of sample plus $0.5 \mathrm{~mL}$ of $0.2 \mathrm{M} \mathrm{pH} 4.6$ citrate buffer and 1 $\mathrm{mL}$ with ninhydrin solution (1\% Ninidrine, $3 \%$ ascorbic acid in 2-methoxyethanol). Readings were made at $570 \mathrm{~nm}$. A standard curve was made with glutamine and asparagine $(2 \mathrm{mM})$ with values between 28 and $140 \mu \mathrm{g} / \mathrm{mL}$. Results were expressed as $\mu \mathrm{g}$ of total free amino acids per $\mathrm{g}$ of plant material.

Soluble proteins were extracted [33] with modification: phosphate buffer $\mathrm{pH}$ 7.5 and $100 \mathrm{mM}$, with the addition of $1 \mathrm{mM}$ EDTA, $3 \mathrm{mM}$ 1,4-dithiothreitol (DTT), 4\% polyvinylpyrrolidone (PVP) (w/v) and $1 \mathrm{mM}$ phenylmethylsulfonyl fluoride (PMSF). The solution was homogenized by vortex for 10 seconds at low speed, and after, centrifuged at $9.000 \times \mathrm{g}$ for $15 \mathrm{~min}$. The supernatant was collected for measuring at $595 \mathrm{~nm}$. The standard curve was built with bovine serum albumin (BSA) at $0.2 \%(\mathrm{w} / \mathrm{v})$.

The organically grown red beat experiment was conducted at the organic vegetables production research area, where an organic system was implemented eleven years ago, at the Federal University of Paraná, under the geographical coordinates $25^{\circ} 25^{\prime} \mathrm{S}$ and $49^{\circ} 06^{\prime} \mathrm{W}$ at an altitude of $920 \mathrm{~m}$. The climate, according to Köppen classification is temperate type $\mathrm{Cfb}$. The soil is classified as yellowish oxisol with medium texture. Chemical analysis of the $0-20 \mathrm{~cm}$ layer of soil in the field indicated the following average values: $\mathrm{pH}\left(\mathrm{CaCl}_{2}\right)=6.30$; $\mathrm{pH}$ SMP $=$ $6.60 ; \mathrm{Al}^{3+}=0 ; \mathrm{H}^{+}+\mathrm{Al}^{3+}=3.20 \mathrm{cmol} \cdot \mathrm{dm}^{-3} ; \mathrm{Ca}^{2+}=13.0 \mathrm{cmol} \cdot \mathrm{dm}^{-3} ; \mathrm{Mg}^{2+}=6.50$ 
$\mathrm{cmol} \cdot \mathrm{dm}^{-3} ; \mathrm{K}^{+}=0.87 \mathrm{cmol} \cdot \mathrm{dm}^{-3} ; \mathrm{P}=73.20 \mathrm{mg} \cdot \mathrm{dm}^{-3} ; \mathrm{C}=39.7 \mathrm{~g} \cdot \mathrm{dm}^{-3}$; soil base saturation $=86 \%$ and CEC $=23.57 \mathrm{cmol} \cdot \mathrm{dm}^{-3}$.

Fifteen days prior to planting, the soil was prepared with the incorporation of $5 \mathrm{t} \cdot \mathrm{ha}^{-1}$ of organic compost with the following average values: $\mathrm{N}=14.4 \mathrm{~g} \cdot \mathrm{kg}^{-1} ; \mathrm{P}$ Mehlich $=10.6 \mathrm{~g} \cdot \mathrm{kg}^{-1} ; \mathrm{K}=11.3 \mathrm{~g} \cdot \mathrm{kg}^{-1} ; \mathrm{Ca}=31.7 \mathrm{~g} \cdot \mathrm{kg}^{-1} ; \mathrm{Mg}=6.8 \mathrm{~g} \cdot \mathrm{kg}^{-1} ; \mathrm{C}=384$ $\mathrm{g} \cdot \mathrm{kg}^{-1} ; \mathrm{pH}=7.1 ; \mathrm{C} / \mathrm{N}=27.6$. The soil fertilization was done according to the Brazilian regulation for organic agriculture.

The red beet cultivars Early Wonder 2000 and Scarlet Super F1-hybrid (Top Seed ${ }^{\circledR}$ ) seedlings were obtained as described above, but without treatment applications they were planted spaced at $0.30 \times 0.10 \mathrm{~m}$, arranged in $1.20 \mathrm{~m}$ wide and $36 \mathrm{~m}$ long planting beds (March 2016).

At the $15^{\text {th }}$ day after planting, weekly foliar applications $(n=6)$ of aqueous suspensions were started with $A p b$ in two concentrations $\left(1.5 \mathrm{~g} \cdot \mathrm{L}^{-1}\right.$ and $3 \mathrm{~g} \cdot \mathrm{L}^{-1}$ ) and the control (water sprays), resulting in a $2 \times 3$ factorial scheme totaling 6 treatments. The experimental design was completely randomized, with five replications. At harvest, 80 days after planting, 8 plants of the two central lines (1.0 $\mathrm{m}^{2}$ ) were harvested to quantify the following characteristics: fresh weight ( $f w$ ), dry weight $(d w)$, beet diameter and yield.

Data were tested for homogeneity of variances by Bartlett's test and then analyzed by ANOVA. When significant, data obtained from seedlings experiment were submitted to regression analysis, with the most efficient concentration related to the measured variables obtained from the first derivative of the regression equation, equating it to zero. Data from bioassays and organically grown red beet had it averages compared by Tukey's test $(p<0.05 ; p<0.01)$. The Software ASSISTAT version 7.7 Beta was used for statistical analysis [34].

\section{Results and Discussion}

The rooting bioassay identified the $A p b$ bioactivity, as shown at Figure 1. The

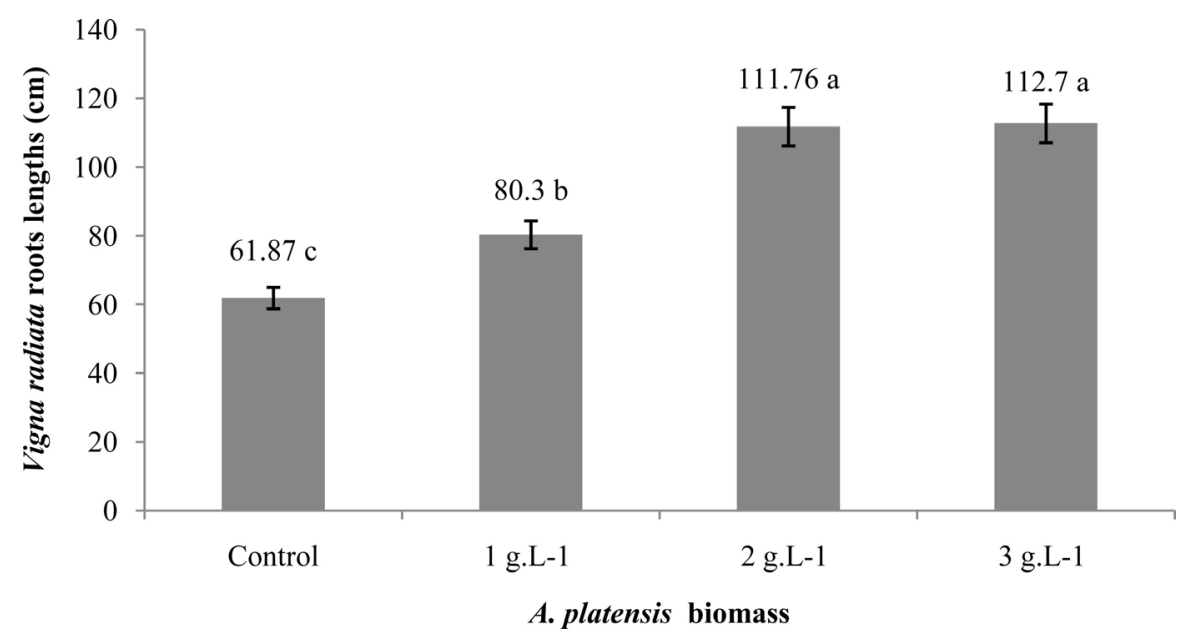

Figure 1. Mung bean (Vigna radiata) roots lengths using 1, 2 and $3 \mathrm{~g} \cdot \mathrm{L}^{-1}$ of $A$. platensis lyophilized biomass on distilled water solution and a control. At the same letter in the columns, the values did not differ by Tukey's test $(p<0.05)$. Bars represent standard error. 
mung bean root growth is widely used to identify biological effects of many kind of sources, as plant growth promoting bacteria [24], plant growth regulators and hormone-like substances [13], relating the improvement of roots length to the source bioactivity.

It is know that Cyanobacteria can stimulate plant metabolism through their bioactive compounds and thus promote plant growth [35]. Among the reported potential bioactive compounds found in these organisms, as hormones [6], polyamines [13] and amino acids [10], being the last one found at high amount in A. platensis biomass [11].

The total free amino acid content on $A p b$ was of $590 \mathrm{mg} \cdot \mathrm{g}^{-1}(d w)$, value close to previously reported on literature [36]. Therefore, is possible to relate the amino acid content on $A p b$ to the bioactivity found on rooting bioassay, taking into account that these compounds are a part of a possible plant growth promoting "package".

The amino acids $(A A)$ play a key role in the nitrogen metabolism efficiency. It is the first compound produced in the assimilation of this element, forming the amides glutamine and asparagine, and from these, the transport of $\mathrm{N}$ for example to chlorophyll synthesis and new $A A$ synthesis pathways [37], by this way stimulating the plant growth and development [38] [39].

The red beet seedlings expressed good plant growth promoting capacity of $A p b$, displaying linear increases on all biometric variables (Figure 2) in function of the increasing on $A p b$ concentration on applied solution. Seedlings leaves shown a $22.78 \%$ increase in its fresh weight compared to the control (Figure 2(a)), and the leaf area (Figure 2(b)) expanded 34.68\%.

The linear increment on growth due to the increasing $A p b$ concentrations, also occurred with the seedlings roots. Fresh and dry root weight (Figure 2(c)) presented increases of $19.61 \%$ and $10.88 \%$ respectively, as well the increase of $27.9 \%$ in total root length (Figure 2(d)).

The effects on seedlings growth are related to biochemical alterations, that were well identified by the increases in chlorophylls, sugar, total free amino acids and proteins (Figure 3 ) due to $A p b$ applications.

The N-Tester ${ }^{\circledR}$ chlorophyll index (Figure 3(a)) and the leaves chlorophyll (ChI) content (Figure 3(b)) showed a linear increment response to $A p b$. At similar result, a higher accumulation of $\mathrm{Chl}$ on Pisum sativa leaves treated with cyanobacteria was attributed to the increase on leaves area, within improving on primary metabolism, as the increase of sugar in leaves [4]. However, the leaves expansion could be a consequence of the stimulus to chlorophyll synthesis, photosynthesis, and increase on sugar content, with all of these pathways related to the $A A$ metabolism on plants [40].

The increase on $C h l$ by $A A$ application was previously reported regarding to the biosynthesis of aminolevulinic acid from the intact carbon skeleton of exogenously applied L-glutamic acid [41], and the joint increases of $C h l, A A$ and plant growth by $A A$ application, were also found by use of fermentation based 

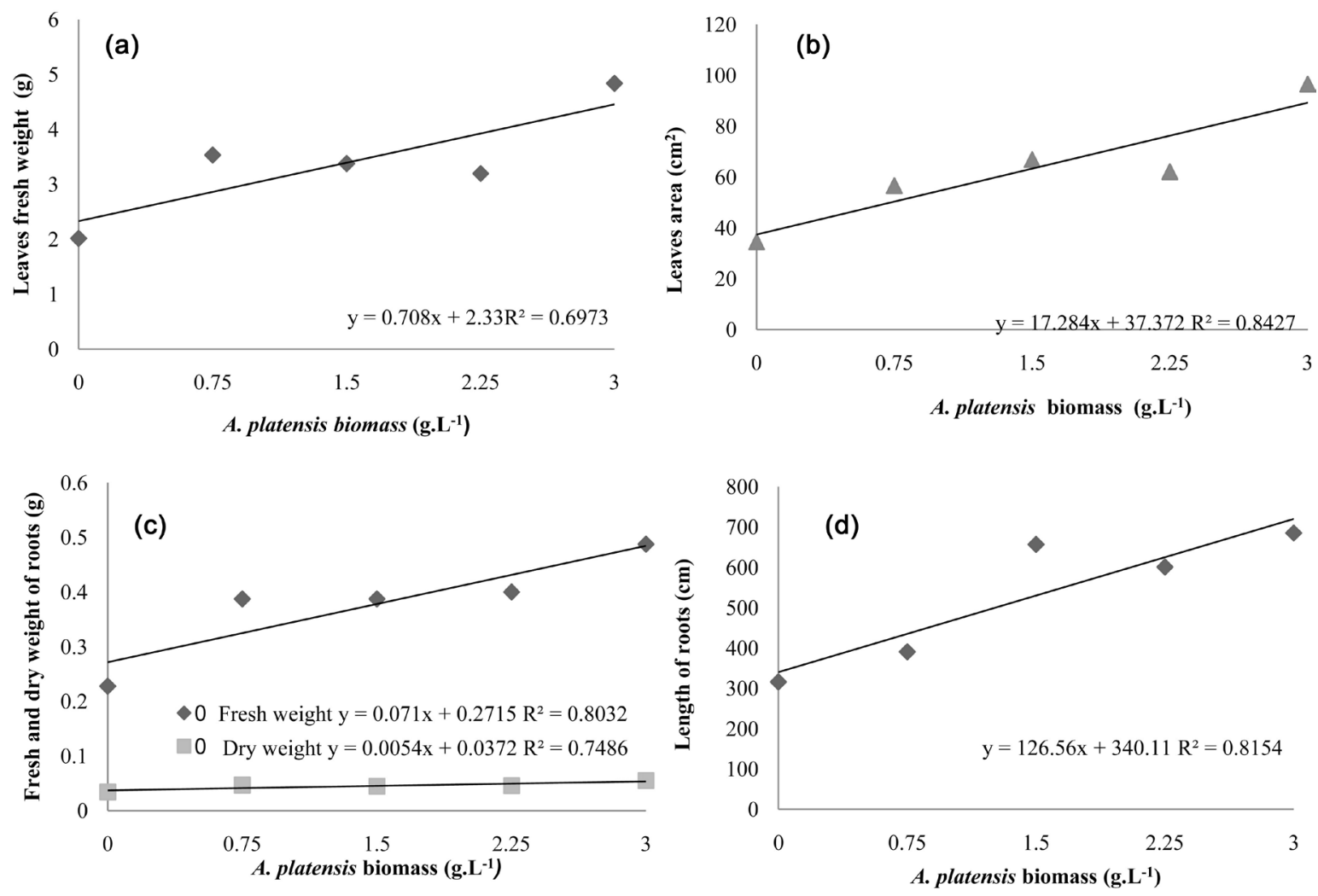

Figure 2. (a) F fresh weight (g); (b) Aerial leaves area $\left(\mathrm{cm}^{2}\right)$; (c) Fresh and dry roots weight (g) and (d) Roots length (cm) of red beet seedlings submitted to foliar applications of $A$. platensis lyophilized biomass.
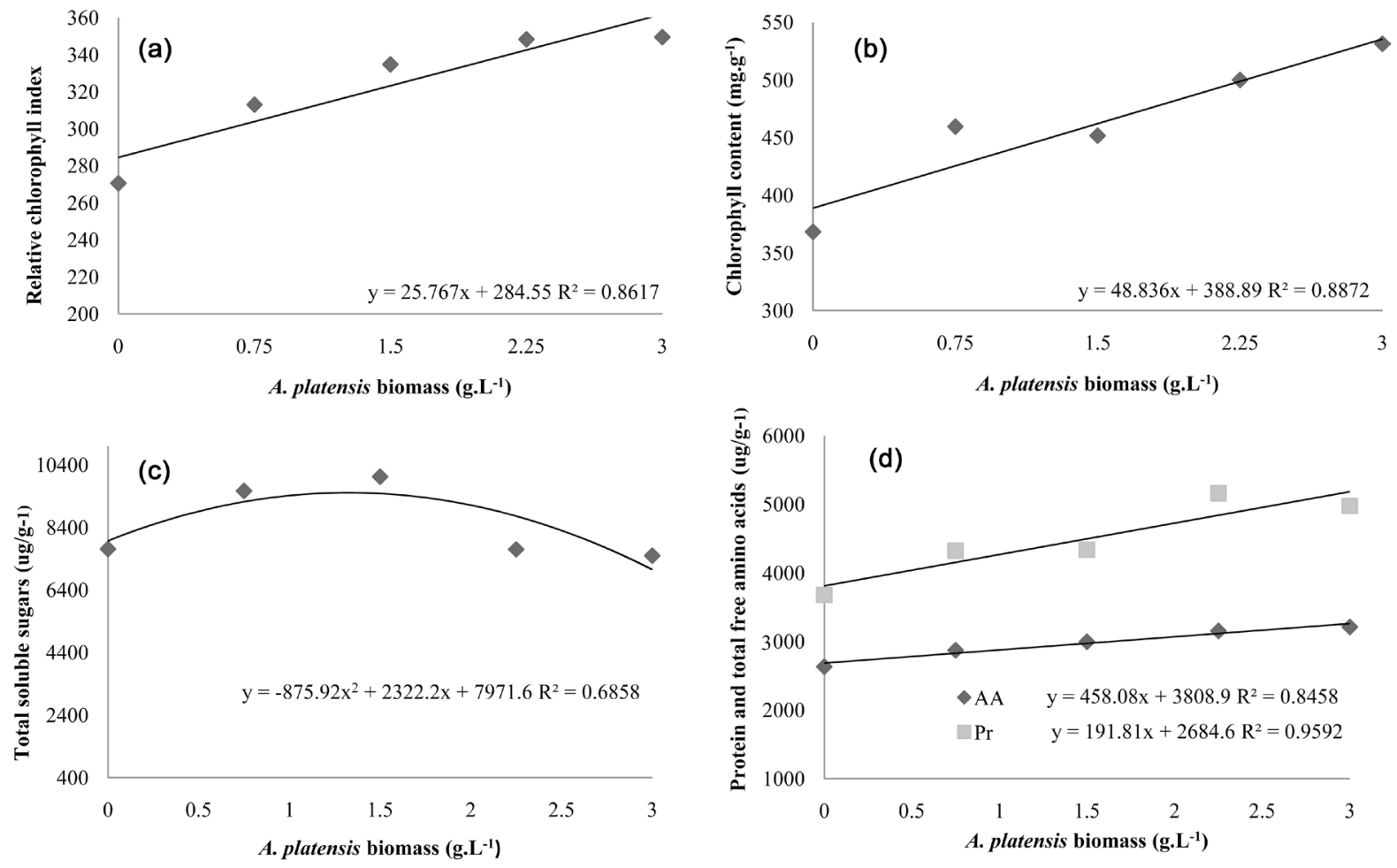

Figure 3. (a) Relative chlorophyll index by N-Tester ${ }^{\circledR}$, (b) Chlorophyll content, (c) Total soluble sugars, (d) Protein (Pr) and total free amino acids (AA), content on red beet seedlings leaves submitted to foliar applications of $A$. platensis lyophilized biomass. 
biofertilizer containing $29 \%$ (w/v) of free $A A$ applied on cabbage seedlings [42]. Figure 3(a), Figure 3(b) and Figure 3(d), express the $A p b$ remarkable eliciting effect on $C h l, A A$ and protein biosynthesis, that are connected to the plant growth promotion (Figure 2). Therefore, taking into account the previous knowledge about the effect of $A A$ applications on plants, allied to the main presence of $A A$ among $A p b$ potential bioactive molecules, it allows to relate the $A p b$ plant growth promoting effect to their $A A$ content.

The total free sugar content in seedling leaves presented a quadratic response to $A p b$ concentrations (Figure 3(c)), showing an increase of $19.3 \%$ at the maximum efficiency concentration $\left(1.32 \mathrm{~g} \cdot \mathrm{L}^{-1}\right)$.

The reduction of total free sugar content in leaves from the concentration of $1.32 \mathrm{~g} \cdot \mathrm{L}^{-1}$ may indicate that these photoassimilates were distributed to the roots, as the root growth was linear according to grown on $A p b$ concentrations, nevertheless; the reduction in leaves sugars did not limited the root growth (Figure 2(d)) or even leaves expansion (Figure 2(b)).

Biochemical changes in leaves justify the growth effects on seedlings, indicating that the bioactivity of $A p b$ is related to plants carbon metabolism, stimulated by $C h l$ synthesis and consequently increase on sugar content, but connected to the nitrogen metabolism, which promotes increase in $A A$ and proteins. In assent with these results, it was previously reported that the exogenous amino acid application may promote nitrogen assimilation in plants by coordinated regulation of $\mathrm{C}$ and $\mathrm{N}$ metabolism [12].

At Table 1, the effect of $A p b$ on beets fresh and dry weight are presented, showing interactions between cultivars and $A p b$ concentrations. Early wonder had higher fresh and dry weights than Scarlet F1, presenting improvements on those variables at both $A p b$ applied concentrations (1.5 and $3.0 \mathrm{~g} \cdot \mathrm{L}^{-1}$ ), while Scarlet $\mathrm{F} 1$ had increases only at $A p b$ highest concentration $\left(3 \mathrm{~g} \cdot \mathrm{L}^{-1}\right)$, indicating different effects in function of genotypes.

There was no interactions between cultivars and $A p b$ applications regarding to beet diameters, yet the differences among cultivars and the effect on hypocotyl expansion by $A p b$ at both concentrations were well characterized (Table 2),

Table 1. Average values of fresh and dry weights of hypocotyl (g) of Early Wonder and Scarlet F1 red beet cultivars at harvest (80 days after planting), submitted to foliar applications of aqueous solutions with $A$. platensis lyophilized biomass at concentrations of 1 and $3 \mathrm{~g} \cdot \mathrm{L}^{-1}$.

\begin{tabular}{ccccccc}
\hline \multirow{2}{*}{ Cultivars } & \multicolumn{3}{c}{ Fresh weight } & \multicolumn{3}{c}{ Dry weight } \\
\cline { 2 - 7 } & Control & $1.5 \mathrm{~g} \cdot \mathrm{L}^{-1}$ & $3 \mathrm{~g} \cdot \mathrm{L}^{-1}$ & Control & $1.5 \mathrm{~g} \cdot \mathrm{L}^{-1}$ & $3 \mathrm{~g} \cdot \mathrm{L}^{-1}$ \\
\hline E. Wonder & $169.5 \mathrm{aB}$ & $256.8 \mathrm{aA}$ & $281.1 \mathrm{aA}$ & $25.6 \mathrm{aB}$ & $42.9 \mathrm{aA}$ & $46.3 \mathrm{aA}$ \\
Scarlet F1 & $111.7 \mathrm{bB}$ & $142.8 \mathrm{baB}$ & $178.8 \mathrm{bA}$ & $18.5 \mathrm{bB}$ & $23.6 \mathrm{bAB}$ & $29.0 \mathrm{bA}$ \\
CV\% & & 16.18 & & & 19.3 & \\
\hline
\end{tabular}

At the same capital letter in the line and lower case at columns, the values did not differ by Tukey's test ( $p<$ $0.05)$. 
showing that "Early wonder" had larger hypocotyl than "Scalet F1", and at both concentrations (1.5 and $3.0 \mathrm{~g} \cdot \mathrm{L}^{-1}$ ) $A p b$ application induced the enlargement of beets equally.

The red beets were grown at the area where the organic system was implemented eleven years ago, on a high fertility soil, presenting yields at control of 33.5 (Scarlet F1) and 50.86 (Early wonder) t.ha ${ }^{-1}$, over than the average of Brazilian yields, that varying from 25 to $40 \mathrm{t} \cdot \mathrm{ha}^{-1}$ [18].

As a consequence of effects on beets weights and diameters, the yield also showed interactions between cultivars and $A p b$ applications, identifying significant improvements. For Early Wonder at the concentration of $3 \mathrm{~g} \cdot \mathrm{L}^{-1}$ it resulted in a $65 \%$ increase, and $60 \%$ in Scarlet F1, both compared to the control (Figure 4).

The result found on yield confirms the $A p b$ bioactivity in promoting plant growth, also found on bioassay and at seedlings growth, related to the main presence of $A A$ among $A p b$ potential bioactive molecules. Amino acids are involved in many kinds of cellular reactions; therefore they can act on plant

Table 2. Average values of hypocotyl diameters $(\mathrm{mm})$ of Early Wonder and Scarlet F1 red beet cultivars at harvest ( 80 days after planting), submitted to foliar applications of aqueous solutions with $A$. platensis lyophilized biomass at concentrations of 1 and $3 \mathrm{~g} \cdot \mathrm{L}^{-1}$.

\begin{tabular}{ccccc}
\hline Cultivars & Control & $1.5 \mathrm{~g} \cdot \mathrm{L}^{-1}$ & $3 \mathrm{~g} \cdot \mathrm{L}^{-1}$ & Av-Cultivars \\
\hline E. Wonder & 65.45 & 76.97 & 77.89 & $73.44 \mathrm{a}$ \\
Scarlet F1 & 56.32 & 62.93 & 67.08 & $62.11 \mathrm{~b}$ \\
Av-Concentrations & $60.89 \mathrm{~b}$ & $69.95 \mathrm{a}$ & $72.49 \mathrm{a}$ & \\
CV\% & 5.6 & & & \\
\hline
\end{tabular}

At the same letter, the values did not differ by Tukey's test $(p<0.05)$, comparing red beet cultivars diameter average values (Av-Cultivars) at column and comparing $A$. platensis biomass concentrations (Av-concentrations) at line.

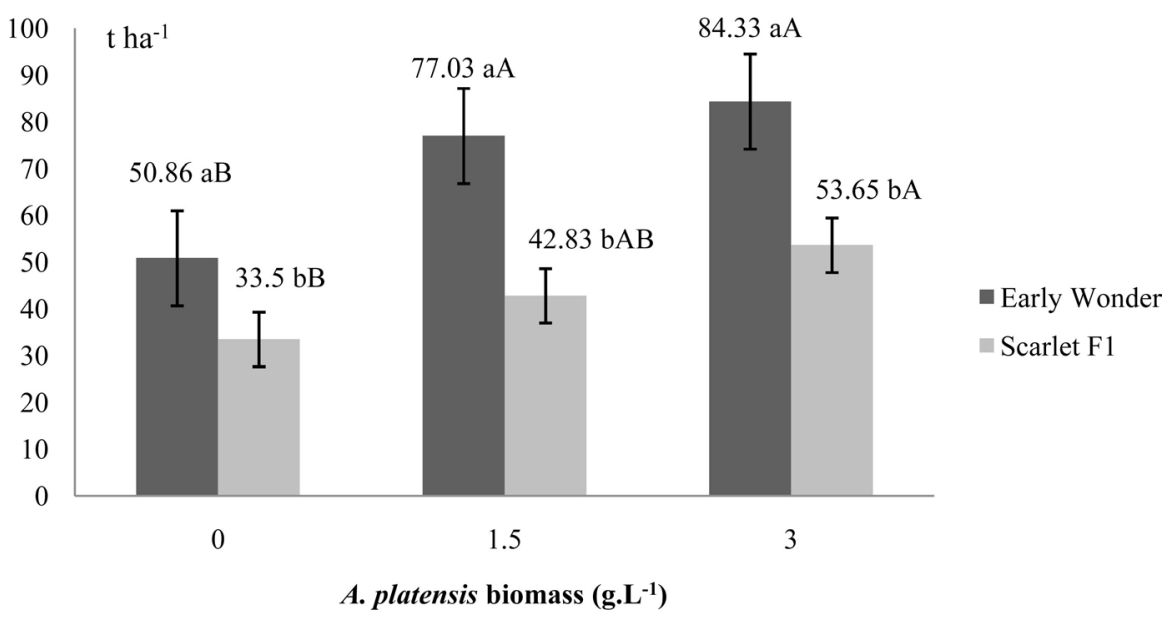

Figure 4. Yield of organically grown Early Wonder and Scarlet super F1 red beet cultivars submitted to foliar applications of $A$. platensis lyophilized biomass. At the same capital letter comparing $A$. platensis concentrations, and lower case comparing cultivars, the values did not differ by Tukey's test $(p<0.05)$. Bars represent standard error. 
growth and development [43] by exogenous supply [42].

As a sequence to the results obtained in this work, further works could investigate the role of $A A$ obtained from $A p b$ as a signaling molecules, theme that recently aroused interest [44] [45].

\section{Conclusion}

The Arthrospira platensis lyophilized biomass free amino acid content is related to the bioactivity found at bioassay, to the growth promotion and metabolic changes found on seedlings, and on red beet hypocotyls expansion and consequent yield gains.

\section{Acknowledgements}

To Brazilian National Council for Scientific and Technological Development (CNPq) 308029/2015-1 PQ2.

\section{References}

[1] Aung, K.L.N. (2011) Effect of Spirulina Biofertilizer Suspension on Growth and Yield of Vigna radiata (L.) Wilczek. Universities Research Journal, 4, 351-355.

[2] Pignolet, O., Jubeau, S., Vaca-Garcia, C. and Michaud, P. (2013) Highly Valuable Microalgae: Biochemical and Topological Aspects. Journal of Industrial Microbiology and Biotechnology, 40, 781-796. https://doi.org/10.1007/s10295-013-1281-7

[3] El Gamal, A.A. (2010) Biological Importance of Marine Algae. Saudi Pharmaceutical Journal, 18, 1-25. https://doi:10.1016/j.jsps.2009.12.001

[4] Osman, M.E.H., El-Sheekh, M.M., El-Naggar, A.H. and Gheda, S.F. (2010) Effect of Two Species of Cyanobacteria as Biofertilizers on Some Metabolic Activities, Growth, and Yield of Pea Plant. Biology and Fertility of Soils, 46, 861-887. https://doi.org/10.1007/s00374-010-0491-7

[5] Shaaban, M.M., El-Saady, A.M. and El-Sayed, A.E.B. (2010) Green Microalgae Water Extract and Micronutrients Foliar Application as Promoters to Nutrient Balance and Growth of Wheat Plants. Journal of American Science, 6, 631-636.

[6] Hussain, A. and Hasnain, S. (2011) Phytostimulation and Biofertilization in Wheat by Cyanobacteria. Journal of Industrial Microbiology and Biotechnology, 38, 85-92. https://doi.org/10.1007/s10295-010-0833-3

[7] Garcia-Gonzalez, J. and Sommerfeld, M. (2016) Biofertilizer and Biostimulant Properties of the Microalga Acutodesmus dimorphus. Journal of Applied Phycology, 28, 1051-1061. https://doi.org/10.1007/s10811-015-0625-2

[8] Trabelsi, L., M'sakni, N.H., Ouada, H.B., Bacha, H. and Roudesli, S. (2009) Partial Characterization of Extracellular Polysaccharides from the Cyanobacterium Arthrospira platensis. Biotechnology and Bioprocess Engineering, 14, 27-31. https://doi.org/10.1007/s12257-008-0102-8

[9] Haroun, S.A. and Hussein, M.H. (2003) The Promotive Effect of Algal Biofertilizers on Growth, Protein Pattern and Some Metabolic Activities of Lupinus termis Plants Grown in Siliceous Soil. Asian Journal of Plant Sciences, 2, 944-951. https://doi.org/10.3923/ajps.2003.944.951

[10] Lisboa, C.R., Pereira, A.M. and Costa, J.A.V. (2016) Biopeptides with Antioxidant Activity Extracted from the Biomass of Spirulina sp. LEB 18. African Journal of Mi- 
crobiology Research, 10, 79-86. https://doi.org/10.5897/AJMR2015.7760

[11] Machado, A.R., Graça, C.S., Assis, L.M. and Souza-Soares, L.A. (2017) An Approach on Characteristics and Potential Assessment of Antioxidant Extracts from Phenolic Microalgae Spirulina sp. LEB-18 and Chlorella pyrenoidosa. Revista de Ciências Agrárias, 40, 264-278. https://doi.org/10.19084/RCA16011

[12] Calvo, P., Nelson L. and Kloepper, J.W. (2014) Agricultural Uses of Plant Biostimulants. Plant Soil, 383, 3-41. https://doi.org/10.1007/s1110

[13] Mógor, A.F., Ördög, V., Lima, G.P.P., Molnár, A. and Mógor, G. (2017) Biostimulant Properties of Cyanobacterial Hydrolysate Related to Polyamines. Journal of Applied Phycology, 29, 453-460. https://doi.org/10.1007/s10811-017-1242-Z

[14] Brasil-MAPA (2011) Instrução Normativa 46. http://sistemasweb.agricultura.gov.br/sislegis/action/detalhaAto.do?method=consul tarLegislacaoFederal

[15] Brasil-MAPA (2016) Instrução Normativa 6. http://sistemasweb.agricultura.gov.br/sislegis/action/detalhaAto.do?method=consul tarLegislacaoFederal

[16] Sediyama, M.A.N., Santos, M.R., Vidigal, S.M. and Salgado, L.T. (2011) Produtividade e Exportação de Nutrientes em Beterraba Cultivada com Cobertura Morta e Adubação Orgânica. Revista Brasileira de Engenharia Agrícola e Ambiental, 15, 883-889. https://doi.org/10.1590/S1415-43662011000900002

[17] Sediyama, M.A.N., Santos, M.R., Vidigal, S.M., Santos, I.C.E. and Salgado, L.T. (2010) Ocorrência de Plantas Daninhas no Cultivo de Beterraba com Cobertura Morta e Adubação Orgânica. Planta Daninha, 28, 717-725. https://doi.org/10.1590/S0100-83582010000400003

[18] Carvalho, L.B. and Guzzo, C.D. (2008) Adensamento da Beterraba no Manejo de Plantas Daninhas. Planta Daninha, 26, 73-82. https://doi.org/10.1590/S0100-83582008000100008

[19] Watthier, M., Silva, M.A.S., Schwengber, J.E., Fonseca, F.D. and Normberg, A. (2016) Produção de Mudas e Cultivo a Campo de Beterraba em Sistema Orgânico de Produção. Revista Brasileira de Agropecuária Sustentável, 6, 51-57. https://doi.org/10.21206/rbas.v6i2.328

[20] Reichert, C.C., Reinehr, C.O. and Costa, J.A.V. (2006) Semicontinuous Cultivation of the Cyanobacterium Spirulina platensis in a Closed Photobioreactor. Brazilian Journal of Chemical Engineering, 23, 23-28. https://doi.org/10.1590/S0104-66322006000100003

[21] Zarrouk, C. (1966) Contribution a L'etude D’une Cyanobacterie: Influence de Divers Facteurs Physiques et Chimiques sur la Croissance et la Photosynthese de Spirulina maxima (Setchell et Gardner) Geitler. PhD Thesis, University of Paris, Paris.

[22] Rajeshwari, K.R. and Rajashekhar, M. (2011) Biochemical Composition of Seven Species of Cyanobacteria Isolated from Different Aquatic Habitats of Western Ghats, Southern India. Brazilian Archives of Biology and Technology, 54, 849-857. https://doi.org/10.1590/S1516-89132011000500001

[23] Moore, S. and Stein, W.H. (1948) Photometric Ninhydrin Method for Use in the Chromatography of Amino Acids. Journal of Biological Chemistry, 176, 367-388. https://www.jbc.org/content/176/1/367.short

[24] Tripepi, R.R. and George, M.W. (1991) Identification of Bacteria Infecting Seedlings of Mung Bean Used in Rooting Bioassays. Journal of American Society for Horticultural Science, 116, 80-84.

[25] Mógor, A.F., Barbizan, T., Pauletti, V., Oliveira, J. and Bettoni, M.M. (2013) Teores 
de Clorofila em Cultivares de Tomateiro Submetidas a Aplicações Foliares de Magnésio. Pesquisa Agropecuária Tropical, 43, 363-369. https://doi.org/10.1590/S1983-40632013000400008

[26] Lichtenthaler, H.K. (1987) Chlorophylls and Carotenoids: Pigments of Photosynthetic Biomembranes. Methods in Enzymology, 148, 350-382. https://doi.org/10.1016/0076-6879(87)48036-1

[27] Pompelli, M.F., França, S.C., Tigre, R.C., Oliveira, M.T., Sacilot, M. and Pereira, E.C. (2013) Spectrophotometric Determinations of Chloroplastidic Pigments in Acetone, Ethanol and Dimethylsulphoxide. Revista Brasileira de Biociências, 11, 52-58.

[28] Lichtenthaler, H.K. and Buschmann, C. (2001) Chlorophylls and Carotenoids: Measurement and Characterization by UV-VIS Spectroscopy. In: Wrolstad, R.E., Acree, T.E., An, H., Decker, E.A., Penner, M.H., Reid, D.S., Schwartz, S.J., Shoemaker, C.F. and Sporns, P., Eds., Current Protocols in Food Analytical Chemistry (CPFA), John Wiley and Sons, New York, F4.3.1-F4.3.8.

[29] Maldonade, I.R., Carvalho, P.G.B. and Ferreira, N.A. (2013) Protocolo para Determinação de Açúcares Totais em Hortaliças pelo Método de DNS. Embrapa Hortaliças-Comunicado Técnico, Brasília, 4 p.

[30] Miller, G.L. (1959) Use of Dinitrosalicylic Acid Reagent for Determination of Reducing Sugar. Analytical Chemistry, 31, 426-428. https://doi.org/10.1021/ac60147a030

[31] Winters, A.L., Lloyd, J.D., Jones, R. and Merry, R.J. (2002) Evaluation of a Rapid Method for Estimating Free Amino Acids in Silages. Animal Feed Science and Technology, 99, 177-187. https://doi.org/10.1016/S0377-8401(02)00112-8

[32] Magné, C. and Larher, F. (1992) High Sugar Content of Extracts Interferes with Colorimetric Determination of Amino Acids and Free Proline. Analytical Biochemistry, 200, 115-118. https://doi.org/10.1016/0003-2697(92)90285-F

[33] Du, C.X., Fan, H.F., Guo, S.R. and Tezuka, T. (2010) Applying Spermidine for Differential Responses of Antioxidant Enzymes in Cucumber Subjected to Short-Term salinity. Journal of the American Society for Horticultural Science, 135, 18-24.

[34] Silva, F.A.S. and Azevedo, C.A.V. (2016) The Assistant Software Version 7.7 and Its Use in the Analysis of Experimental Data. African Journal of Agricultural Research, 11, 3733-3740. https://doi.org/10.5897/AJAR2016.11522

[35] Singh, J.S., Kumar, A., Rai, A.N. and Singh, D.P. (2016) Cyanobacteria: A Precious Bio-Resource in Agriculture, Ecosystem, and Environmental Sustainability. Frontiers in Microbiology, 7, 1-19. https://doi.org/10.3389/fmicb.2016.00529

[36] Campanella, L., Crescentini, G. and Avino, P. (1999) Chemical Composition and Nutritional Evaluation of Some Natural and Commercial Food Products Based on Spirulina. Analusis, 27, 533-540. https://doi.org/10.1051/analusis:1999130

[37] Forde, B.G. and Lea, P.J. (2007) Glutamate in Plants: Metabolism, Regulation, and Signaling. Journal of Experimental Botany, 58, 2339-2358. https://doi.org/10.1093/jxb/erm121

[38] Sun, Y.L. and Hong, S.K. (2010) Effects of Plant Growth Regulators and L-Glutamic Acid on Shoot Organogenesis in the Halophyte Leymus chinensis (Trin.). Plant Cell Tissue and Organ Culture, 100, 317-328. https://doi.org/10.1007/s11240-009-9653-4

[39] Lei, P., Xu, Z., Ding, Y., Tang, B., Zhang, Y., Li, H. and Feng, X. (2015) Effect of Poly( $\gamma$-glutamic acid) on the Physiological Responses and Calcium Signaling of Rape Seedlings (Brassica napus L.) under Cold Stress. Journal of Agriculture and Food Chemistry, 48, 10399-10406. https://doi.org/10.1021/acs.jafc.5b04523 
[40] Layer, G., Reichelt, J., Jahn, D. and Heinz, D.W. (2010) Structure and Function of Enzymes in Heme Biosynthesis. Protein Science, 19, 1137-1161. https://doi.org/10.1002/pro.405

[41] Beale S., Gough, S.P. and Granick, S. (1975) Biosynthesis of Delta-Aminolevulinic Acid from the Intact Carbon Skeleton of Glutamic Acid in Greening Barley. Proceedings of the National Academy of Sciences of the United States of America, 72, 2719-2723. https://doi.org/10.1073/pnas.72.7.2719

[42] Röder, C., Mógor, A.F., Szilagyi-Zecchin, V.J., Fabbrin, E.G.S. and Gemin, L.G. (2015) Uso de Biofertilizante na Produção de Mudas de Repolho. Revista Ceres, 62, 502-505. https://doi.org/10.1590/0034-737X201562050012

[43] Hildebrandt, T.M., Nunes-Nesi, A., Araújo, W.L. and Braun, H.P. (2015) Amino Acid Catabolism in Plants. Molecular Plant, 8, 1563-1579.

https://doi.org/10.1016/j.molp.2015.09.005

[44] Nunes-Nesi, A., Fernie, A.R. and Stitt, M. (2010) Metabolic and Signaling Aspects Underpinning the Regulation of Plant Carbon Nitrogen Interactions. Molecular Plant, 3, 973-996. https://doi.org/10.1093/mp/ssq049

[45] Häusler, R.E., Ludewig, F. and Krueger, S. (2014) Amino Acids-A Life between Metabolism and Signaling. Plant Science, 229, 225-237.

https://doi.org/10.1016/j.plantsci.2014.09.011 